\title{
Oncolytic immunotherapy: dying the right way is a key to eliciting potent antitumor immunity
}

\section{Zong Sheng Guo*, Zuqiang Liu and David L. Bartlett}

Department of Surgery, University of Pittsburgh Cancer Institute, University of Pittsburgh School of Medicine, Pittsburgh, PA, USA

Edited by:

Philippe Fournier, DKFZ, Germany

Reviewed by:

William L. Redmond, Providence Portland Medical Center, USA

Volker Schirrmacher, DKFZ, Germany

Karen Mossman, McMaster

University, Canada

*Correspondence:

Zong Sheng Guo, Department of Surgery, University of Pittsburgh

Cancer Institute, University of

Pittsburgh School of Medicine,

Pittsburgh, PA 15213, USA

e-mail:guozs@upmc.edu

\begin{abstract}
Oncolytic viruses (OVs) are novel immunotherapeutic agents whose anticancer effects come from both oncolysis and elicited antitumor immunity. OVs induce mostly immunogenic cancer cell death (ICD), including immunogenic apoptosis, necrosis/necroptosis, pyroptosis, and autophagic cell death, leading to exposure of calreticulin and heat-shock proteins to the cell surface, and/or released ATP, high-mobility group box 1, uric acid, and other damage-associated molecular patterns as well as pathogen-associated molecular patterns as danger signals, along with tumor-associated antigens, to activate dendritic cells and elicit adaptive antitumor immunity. Dying the right way may greatly potentiate adaptive antitumor immunity. The mode of cancer cell death may be modulated by individual OVs and cancer cells as they often encode and express genes that inhibit/promote apoptosis, necroptosis, or autophagic cell death. We can genetically engineer OVs with death-pathwaymodulating genes and thus skew the infected cancer cells toward certain death pathways for the enhanced immunogenicity. Strategies combining with some standard therapeutic regimens may also change the immunological consequence of cancer cell death. In this review, we discuss recent advances in our understanding of danger signals, modes of cancer cell death induced by OVs, the induced danger signals and functions in eliciting subsequent antitumor immunity. We also discuss potential combination strategies to target cells into specific modes of ICD and enhance cancer immunogenicity, including blockade of immune checkpoints, in order to break immune tolerance, improve antitumor immunity, and thus the overall therapeutic efficacy.
\end{abstract}

Keywords: immunogenic cancer cell death, DAMPs, PAMP, autophagy, tumor-associated antigen, crosspresentation, immune tolerance, antitumor immunity

\section{INTRODUCTION}

Oncolytic viruses (OVs) have been shown to be effective in treating cancer in preclinical models and promising clinical responses in human cancer patients (1-3). OV-mediated cancer therapeutic includes three major mechanisms. The first is the direct infection of cancer and endothelial cells in the tumor tissue leading to direct oncolysis of these cells. The second is necrotic/apoptotic death of uninfected cells induced by anti-angiogenesis and vasculature targeting of the OVs as shown in both animal models and human cancer patients (4-6). The last is the activated innate and adaptive tumor-specific immunity, which exert cytotoxicity to surviving cancer and stromal cells. A number of recent studies have demonstrated that the antitumor immunity has played an important role in the overall efficacy of oncolytic virotherapy, which has been shown to contribute to the efficacy of oncolytic virotherapy (7-14). In the case of oncolytic vesicular stomatitis virus (VSV), reovirus, and herpes simplex virus (HSV), the antitumor immune response is very critical to the overall efficacy of oncolytic virotherapy, sometimes even more important than that of direct oncolysis $(7,9,11,14)$.

Oncolytic viruses provide a number of potential advantages over conventional cancer therapies. First, OVs are tumor-selective antitumor agent, thus providing higher cancer specificity and better safety margin. Second, OV-mediated oncolysis not only leads to regression of tumor size, but this process provides key signals to dendritic cells (DCs) and other antigen presenting cells to initiate a potentially potent antitumor immune response. The immunogenic types of cell death induced by OVs provide danger signal (signal 0 ) and a natural repertoire of tumor-associated antigens (TAAs) to DCs, both required to trigger an adaptive immunity against cancer (15-17). The danger signals include damage-associated molecular pattern (DAMP) and pathogenassociated molecular pattern (PAMP) molecules derived from the OVs. Therefore, this process could provide a highly favorable immunological backdrop for the host to respond and generate potent adaptive antitumor immunity. However, just like other immunotherapeutic regimens for cancer, a number of challenges remain for OVs-mediated immunotherapy. One is that relative inefficiency of delivering OVs to tumor nodules, viral replication within tumor mass, and spread to distant metastases dampens its overall efficacy. Second, most TAAs are self-antigens and thus weakly immunogenic. As we will discuss below, OVs may enhance tumor immunogenicity in many cases. Yet, this low immunogenicity still is a problem due to the highly immunosuppressive tumor microenvironment (TME). Third, a highly immunosuppressive TME in late stages of cancer often suppresses the activities of tumor-infiltrated lymphocytes (TILs) generated either spontaneously or by an immunotherapeutic regimen (18). 
In this review, we will discuss different modes of cell death induced by various OVs, their potential effects on the subsequent antitumor immunity. Then we discuss rationales and strategies of inducing ideal types of cancer cell death by either genetic modification on OVs or by combination with specific antitumor agents that lead to specific mode of immunogenic cancer cell death (ICD). Finally, we provide some perspective on future combination strategies to improve antitumor immunity for enhanced overall efficacy of virotherapy.

\section{OV: TUMOR SELECTIVITY AND RELEVANCE OF ANIMAL MODEL}

Ideally, OVs selectively infect and replicate in cancer cells and cancer-associated endothelial cells, leading to direct oncolysis and subsequent antitumor activities without harming normal tissue (1-3). Some OVs display intrinsic tumor tropism (naturally occurring OVs), while others obtain their tumor selectivity through natural evolution or genetic engineering. The mechanisms underlying the tumor selectivity may include altered signaling pathways of ataxia telangiectasia mutated (ATM), epidermal growth factor receptor (EGFR), p53, PKR, Ras, RB/E2F/p16, Wnt, anti-apoptosis, or defects in cellular innate immune signaling pathways or hypoxia conditions in the $\operatorname{TME}(1,3,19,20)$.

Viruses display strict viral tropism, specific for a cell type, tissue, or species. However, OVs often broaden their tropism to cancer cells from non-permissive species to various degrees. As an example, human adenovirus (Ad) does not infect normal murine cells, yet infect murine cancer cells even though the production of infectious virus progeny is often limited. A recent study may provide some answer to this phenomenon. McNeish et al. have found that murine cancer cells support viral gene transcription, mRNA processing, and genome replication of human Ad, but there is a profound failure of viral protein synthesis, especially late structural proteins with reduced loading of late mRNA onto ribosomes. Interestingly, in trans expression of the non-structural late protein L4-100K increases both viral mRNA loading on ribosomes and late protein synthesis, accompanied by reduced phosphorylation of eIF $2 \alpha$ and improved anticancer efficacy (21). The key point is that some OVs display aberrant, non-productive infection in nonnative hosts such as mouse cells, leading to mode of cancer cell death different from the mode of cell death in native host. As we will discuss extensively later, the mode of cancer cell death dictates to a significant degree the subsequent antitumor immunity. As a consequence, the OV-elicited antitumor immunity in tumor models of syngeneic animals might not be relevant to the situation in human cancer patients. This is an often overlooked issue when tumor models in animals are chosen along with OVs as therapeutic models for human cancer.

\section{SIGNAL 0: DAMPS AND PAMPS \\ PAMPS: SIGNAL OS FROM PATHOGENS}

In the late 1980s, Charles Janeway proposed that the immune system protects the host against infectious pathogens by presenting the molecules as signal 0s, which is what now called PAMPs, to the antigen presenting cells $(22,23)$. PAMPs consist of essential components of microorganisms that direct the targeted host cells, key components in the innate immune arm, to distinguish "self" from "non-self," and promote signals associated with innate immunity (24). Major PAMPs are nucleic acids (DNA, doublestranded RNA, single-stranded RNA, and 5' -triphosphate RNA), proteins (lipoproteins and glycoproteins), as well as other components of the cell surface and membrane $(17,25)$. Interestingly, defective viral genomes arising in vivo are a critical danger signal for triggering antiviral immunity in the lung (26).

This concept of PAMPs has been strongly supported by the discovery of several classes of pattern-recognition receptors (PRRs). These PRRs include the toll-like receptors (TLRs), retinoic acid-inducible gene-1 (RIG-1)-like receptors (RLRs), nucleotide oligodimerization domain (NOD)-like receptors (NLRs), AIM2like receptors, and the receptor for advanced glycation end products (RAGE) $(17,27)$. It is now well accepted that both DAMPs and PAMPs stimulate the innate immune system through PRRs. DCs express a wide repertoire of these PRRs. The binding of PAMP to its receptors on the APC activates the DCs $(28,29)$.

\section{DAMPs: SIGNAL Os FROM HOST}

Matzinger proposed what is known now as the "danger theory" in 1994 (30). In the theory, it proposed that the immune system can distinct self from non-self and dangerous from innocuous signals. In this model, APCs are activated by both PAMPs and DAMPs from distressed or damaged tissues or microbes. The theory has been well accepted in recent years, as we have learned more and more about how dying cells alert immune system to danger (31). Over the years, a number of endogenous danger signals have been discovered. For examples, it was shown that uric acid functions as a principal endogenous danger signal, which is released from injured cells (32).

Damage-associated molecular patterns are molecules derived from normal cells that can initiate and perpetuate immunity in response to cell stress/tissue damage in the absence of pathogenic infection. DAMPs vary greatly depending on the type of cell and injured tissue. They can be proteins, DNA, RNA, or metabolic products. Protein DAMPs include intracellular proteins, such as high-mobility group box 1 (HMGB1), heat-shock proteins (HSPs), and proteins in the intracellular matrix that are generated following injury, such as hyaluronan fragments (33). HMGB1 is one prototypic DAMP $(34,35)$. The protein DAMPs can be localized within the nucleus, cytoplasm, cell membrane, and in exosomes, the extracellular matrix, or as plasma components (17). Other types of DAMPs may include DNA, ATP, uric acid, and heparin sulfate. It is interesting to note that mitochondria are a rich and unique source of DAMPs, including formyl peptides, the mitochondrial DNA (mtDNA)-binding proteins, transcription factor TFAM, and mtDNA itself (36). Following interactions between DAMPs and PRRs on the target cells, the intracellular signaling cascades triggered by the interactions between DAMPs and PRRs lead to activation of genes encoding inflammatory mediators, which coordinate the elimination of pathogens, damaged, or infected cells (27). In cancer, chronic inflammation and release of DAMPs promotes cancer, while acute inflammation of release/presentation of DAMPs may induce potent antitumor immunity and helps in cancer therapy $(35,37)$. Based on the work in chemotherapy and radiation therapy, the concept of ICD of cancer cells has been established about 10 years ago $(37,38)$. As we will discuss below, 
this concept leads to development of novel strategies for cancer therapeutics.

\section{OVs INDUCE MOSTLY MULTIMODALITY ICD AND RELEASE/PRESENT DANGER SIGNAL MOLECULES}

Investigators have long been interested in what defines the immunogenicity of cancer cells and how we can enhance the immunogenicity for the purpose of immunotherapy. Pioneering work by Lindenmann and Klein almost half a century ago demonstrated that viral oncolysis of cancer cells by influenza virus increases immunogenicity of tumor cell antigens (39). However, it was not clear how this immunogenicity was enhanced at the time. Over a decade ago, it was found that tumor immunogenicity is enhanced by cell death via induced expression of HSPs (40). A few years ago, investigators working on chemotherapy and radiation for cancer therapy have led to this new concept as they classify the types of cancer cell death by the immunological consequence, into "immunogenic cancer cell death" (ICD) and "non-immunogenic cancer cell death" (NICD) (41-43). The original concept of ICD includes only "immunogenic apoptosis." We and others have recently proposed that ICD includes not only immunogenic apoptosis, but also necroptosis, necrosis, autophagic cell death, and pyroptosis of cancer cells (Figure 1) $(44,45)$. Basically, cancer cells dying via ICD have the following common features as summarized by Tesniere, Zitvogel, Kroemer, and their colleagues (46). They stated that, "some characteristics of the plasma membrane, acquired at pre-apoptotic stage, can alarm immune effectors to recognize and then attack these pre-apoptotic tumor cells. The signals that mediate the immunogenicity of tumor cells involve elements of the DNA damage response, elements of the endoplasmic reticulum stress response, as well as elements of the apoptotic response" (46). For cells undergoing pre-apoptotic phase, they may express "danger" and "eat-me" signals on the cell surface (calreticulin and HSPs) or can secrete/release immunostimulatory factors (cytokines, ATP, and HMGB1) to stimulate innate immune effectors (46). For other types of ICD, extracellular ATP, HMGB1, uric acid, other DAMPs, and PAMPs released in the mid or late phases functions as potent danger signals, thus making it highly immunogenic.

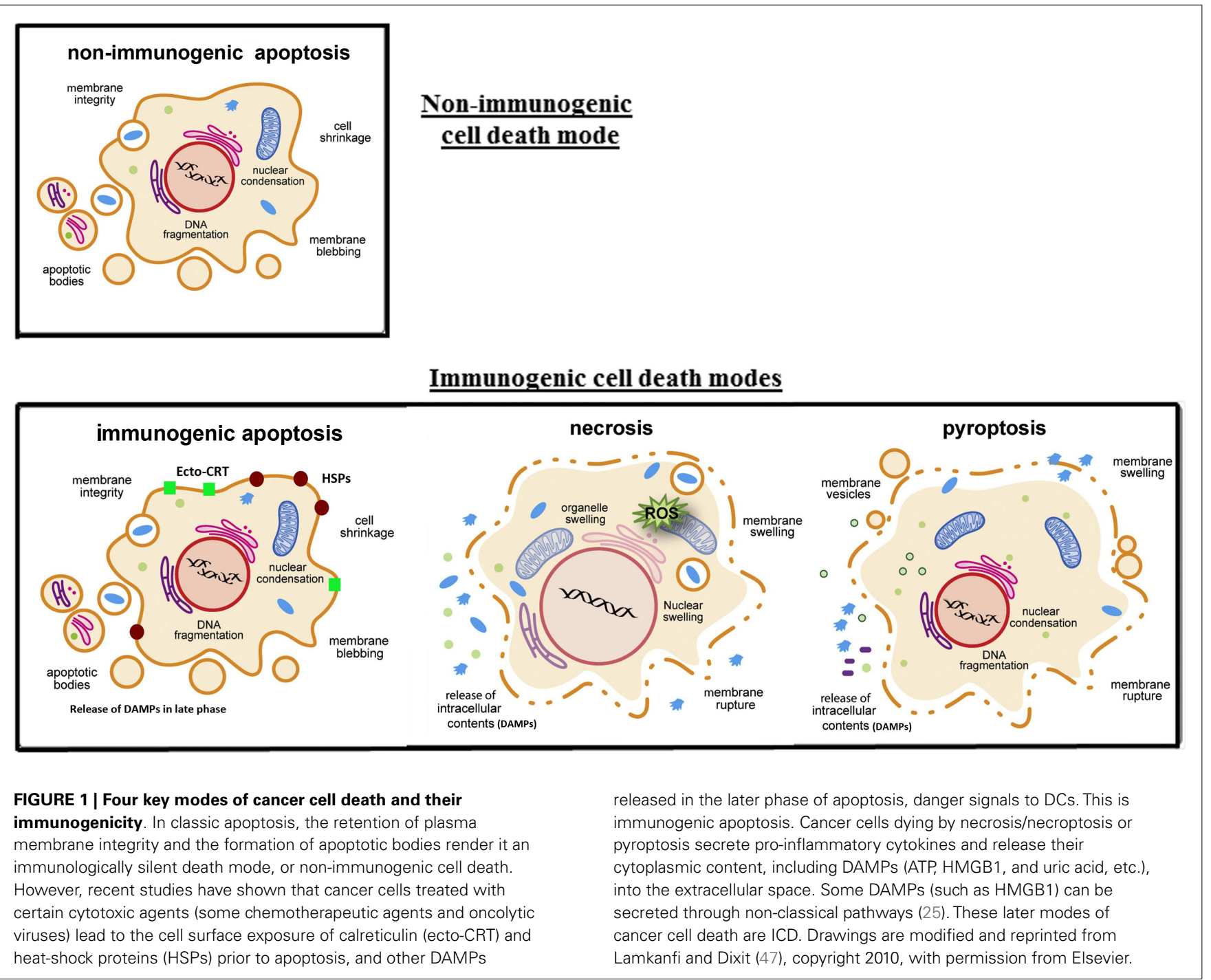


Oncolytic viruses kill cancer and associated endothelial cell through a variety of types of cell death as classically defined by the morphological and ultrastructural changes of dying cells. These include apoptosis, necrosis, necroptosis, pyroptosis, and autophagic cell death, often with one as the predominant form of death for a particular OV. By the new definition, cancer cell death induced by OVs is mostly immunogenic (Table 1). Probably all oncolytic Ads induced autophagic cell death in cancer cells (4851). Coxsackievirus B3 (CVB3) induces immunogenic apoptosis in human non-small cell lung cancer cells (52). Measles virus (MV) causes ICD in human melanoma cells, because inflammatory cytokines and HMGB1 are released, and DCs are activated by MVinfected cancer cells (53). HMGB1 release often happens in late stage of apoptosis, during autophagy process and in necrotic cells infected with OVs. We first reported in 2005 that human cancer cells infected by an oncolytic poxvirus, led to necrotic/apoptotic death pathways and release of HMGB1 (54). Later studies have confirmed and extended the findings of HMGB1 release in cancer cells infected with Ads (12), CVB3 (52), an MV (53), vaccinia viruses (VVs) (55-57), HSV (14, 58), and parvovirus H-1 (H-1PV) (59). Extracellular ATP is another potent danger signal released from OV-infected cancer cells $(12,52,56,60)$. The third danger

Table 1 | Oncolytic viruses lead to specific mode of immunogenic cell death and exposure/release of DAMPs/PAMPs.

\begin{tabular}{|c|c|c|c|c|c|}
\hline OV & DAMP/PAMP & Receptor & Type of cell death & Immunological functions & Reference \\
\hline $\begin{array}{l}\text { Ad5/3-D24- } \\
\text { GM-CSF; } \\
\text { CVB3; vvDD }\end{array}$ & ATP & $\begin{array}{l}\mathrm{P} 2 \mathrm{Y} 2 \text { and } \\
\mathrm{P} 2 \mathrm{X} 7\end{array}$ & $\begin{array}{l}\text { Necrosis, autophagic cell death, } \\
\text { and immunogenic apoptosis }\end{array}$ & $\begin{array}{l}\text { Function as a "find-me" signal, and cause } \\
\text { NLRP3-inflammasome-based IL-1 } \beta \text { production }\end{array}$ & $(52,56,60)$ \\
\hline $\begin{array}{l}\text { Ad5/3-D24- } \\
\text { GM-CSF; } \\
\text { CVB3 }\end{array}$ & $\begin{array}{l}\text { Ecto-CRT } \\
\text { (calreticulin) }\end{array}$ & CD91 & $\begin{array}{l}\text { Immunogenic apoptosis (either } \\
\text { pre-apoptotic, early or mid } \\
\text { apoptotic surface exposure) or } \\
\text { secondary necrosis }\end{array}$ & $\begin{array}{l}\text { Function as an "eat-me" signal and it is a potent } \\
\text { mediator of tumor immunogenicity crucial for } \\
\text { elicidation of antitumor immunity }\end{array}$ & $(52,60)$ \\
\hline $\begin{array}{l}\text { Parvovirus } \mathrm{H}-1 \\
\text { (H-1PV) }\end{array}$ & $\begin{array}{l}\text { HSPs: (HSP90, } \\
\text { HSP70, } \\
\text { Hsp72) }\end{array}$ & $\begin{array}{l}\text { CD91, TLR2, } \\
\text { TLR4, SREC1, } \\
\text { and FEEL1 }\end{array}$ & $\begin{array}{l}\text { Immunogenic apoptosis } \\
\text { (surface exposure) or necrosis } \\
\text { (passively released) }\end{array}$ & $\begin{array}{l}\text { Surfaced-exposed HSP90 can mediate adaptive } \\
\text { antitumor immunity, while secreted HSP90 can } \\
\text { inhibit TGF- } \beta 1 \text { activation; Leads to TAA-specific } \\
\text { antitumor immunity }\end{array}$ & $(65-67)$ \\
\hline $\begin{array}{l}? \text { (Not } \\
\text { identified) }\end{array}$ & Histones & TLR9 & $\begin{array}{l}\text { Apoptosis (cell surface } \\
\text { exposure) or accidental } \\
\text { necrosis (passively released) }\end{array}$ & $\begin{array}{l}\text { Released histones can cause initiation of } \\
\text { TLR9-MyD88-mediated inflammation }\end{array}$ & (68) \\
\hline $\begin{array}{l}\text { Many OVs: Ad; } \\
\text { HSV; MV; VV; } \\
\text { H-1PV }\end{array}$ & HMGB1 & $\begin{array}{l}\text { TLR2, TLR4, } \\
\text { RAGE , and } \\
\text { TIM3 }\end{array}$ & $\begin{array}{l}\text { Immunogenic apoptosis; } \\
\text { necrosis; autophagic cell death }\end{array}$ & $\begin{array}{l}\text { Activate macrophages and DCs; recruit } \\
\text { neutrophils; promote in vivo the production of } \\
\text { IFN- } \gamma, \mathrm{TNF}-\alpha, \mathrm{IL}-6, \mathrm{IL}-12 \text {, and antigen-specific } \\
\text { activation of CD8 }{ }^{+} \mathrm{T} \text { cells }\end{array}$ & $\begin{array}{l}(53,54,56 \\
57,59,60)\end{array}$ \\
\hline MV-eGFP & $\mathrm{IL}=6$ & $\begin{array}{l}\text { IL-6R and } \\
\text { GP130 }\end{array}$ & Necroptosis & $\begin{array}{l}\text { A cell type-specific endokine DAMP with potent } \\
\text { pro-inflammatory activity }\end{array}$ & $(53)$ \\
\hline $\begin{array}{l}\text { Telomelysin } \\
\text { (Ad) }\end{array}$ & Uric acid & P2Y6 & Autophagic cell death & $\begin{array}{l}\text { Stimulate the production of inflammatory } \\
\text { cytokines such as IL-1, TNF- } \alpha \text {, and IL-6 and } \\
\text { chemotactic factors for neutrophils such as } \\
\text { IL-8/CXCL8 and S100A8/A9 }\end{array}$ & $(61,69)$ \\
\hline $\begin{array}{l}\text { Newcastle } \\
\text { disease virus } \\
\text { (NDV) }\end{array}$ & $\begin{array}{l}\text { dsRNA and } \\
\text { other PAMPs }\end{array}$ & $\begin{array}{l}\text { TLR3; and by } \\
\text { the } \\
\text { cytoplasmic } \\
\text { receptors } \\
\text { MDA-5 and } \\
\text { RIG-I }\end{array}$ & $\begin{array}{l}\text { Immunogenic Apoptosis; } \\
\text { autophagy }\end{array}$ & $\begin{array}{l}\text { (1) Upregulation of HLA antigens and ICAM-1; (2) } \\
\text { induction of type I IFNs and chemokines (CCL5 } \\
\text { and CXCL10); (3) activate DCs and T effector cells } \\
\text { but also to block Treg cells; (4) local therapy with } \\
\text { oncolytic NDV induces inflammatory immune } \\
\text { infiltrates in distant tumors, making them } \\
\text { susceptible to systemic therapy }\end{array}$ & $(70-74)$ \\
\hline Reovirus & $\begin{array}{l}\text { The virus itself } \\
\text { (PAMP) }\end{array}$ & $\begin{array}{l}\text { Dendritic cells } \\
\text { (DCs) }\end{array}$ & $\begin{array}{l}\text { (Cancer cell independent } \\
\text { mechanism) }\end{array}$ & $\begin{array}{l}\text { Induce DC maturation and stimulate the } \\
\text { production of the pro-inflammatory cytokines } \\
\text { IFN- } \alpha, T N F-\alpha, I L-12 p 70 \text {, and IL-6. Reovirus directly } \\
\text { activates human DC and that reovirus-activated } \\
\text { DCs stimulate innate killing by not only NK cells, } \\
\text { but also T cells }\end{array}$ & $(75)$ \\
\hline
\end{tabular}


signal molecule released from OV-infected cells is uric acid (61). Some OVs may induce cell death partly through pyroptosis, a caspase-1 dependent inflammatory form of cell death (62). Both necrotic cells and pyroptotic cells release ATP more efficiently than apoptotic cells do. Pyroptotic cells, just like apoptotic cells, actively induce phagocytosis by macrophages using "eat-me" and "findme" signals (63). Cytolytic immune cells, elicited by OVs or other agents, kill additional cancer cells leading to release of DAMPs such as HMGB1 (64). In summary, most OVs induce ICD of cancer cells and present/release a number of potent danger signals, and TAAs to DCs to trigger adaptive immune response (Table 1).

Cancer cell death induced by some OVs has not been examined for their direct features of ICD. However, other properties suggest that cancer cells infected by the OV are immunogenic, or the viruses themselves are highly immunogenic. Newcastle disease virus (NDV) is a well-studied virus for its virology and immunostimulatory properties (76). NDV induces cancer cells into apoptosis (70), with autophagy taking place during the process (71). Human cancer cells infected by NDV show upregulation of HLA class I and II antigens, and costimulatory molecule ICAM-1, as well as induction of IFNs, chemokines (IP10 and RANTES) before apoptosis (72). Moreover, the inflammatory conditions and type I IFNs inhibit Treg cells (73). With these potent immunostimulatory properties, local administration of oncolytic NDV overcomes systemic tumor resistance to immunotherapy by blockade of immune checkpoints (74). Another RNA virus, reovirus, also induces cancer cells into apoptosis $(77,78)$, with autophagy taking place in the process (79-81). Melanoma cells infected with reovirus release a range of inflammatory cytokines and chemokines while IL-10 secretion is abrogated (82). These molecules may provide a useful danger signal to reverse the immunologically suppressive environment of this tumor. Even more interestingly, reovirus can also interact with DCs directly and matured DCs activate NK and T cells (75) (Table 1). Those activated NK and T cells exert innate killing of cancer cells. This innate effector mechanism may complement the virus's direct cytotoxicity and thus induced adaptive antitumor immunity, potentially enhancing the efficacy of reovirus as a therapeutic agent (75).

\section{OV-INDUCED AUTOPHAGY IN CANCER CELLS PROMOTES CROSS-PRESENTATION OF TAAs AND ELICITS STRONGER ANTITUMOR IMMUNITY}

Autophagy mediates sequestration, degradation, and recycling of cellular organelles and proteins, and intracellular pathogens. It is not too surprising that autophagy plays roles in both innate and adaptive immunity $(17,83)$. A number of OVs, such as Ad (48-51), encephalomyocarditis virus (84), HSV $(62,85,86)$, influenza virus (87), NDV (71), reovirus (79-81), and VSV (84), induce autophagy in infected cancer cells. Evidence shows that autophagy may enhance tumor immunogenicity. One mechanism is that autophagic cells selectively release DAMPs such as ATP (88, 89), HMGB1 (90), and uric acid (61). The other mechanism is that autophagy promotes antigen cross-presentation from cancer cells by DCs to naïve T cells. It stimulates antigen processing for both MHC class II (91), and MHC class I pathways. These have been demonstrated for endogenous viral antigens during HSV-1 infection (85), and for cross-presentation of TAAs from uninfected cancer cells (92), and influenza A virus-infected tumor cells (93). In other words, autophagy within the antigen donor cells facilitates antigen cross-priming to generate TAA-specific or virus-specific $\mathrm{CD}^{+} \mathrm{T}$ cells (92-95). This property has been explored for cancer vaccines (96), and for enhanced OV-mediated antitumor effects in the future (97).

\section{VIRUSES OFTEN ENCODE SPECIFIC GENES TO MODULATE APOPTOSIS, AUTOPHAGY, NECROPTOSIS, AND POSSIBLY OTHER DEATH PATHWAYS}

Successful viral replication requires the efficient production and spread of progeny virus, which can be achieved through efficient evasion of host defense mechanisms that limit replication by killing infected cells. Viruses have thus evolved to encode genes whose products function to block or delay certain cell death pathways until sufficient progeny have been produced (47). These gene-encode products target a variety of strategic points in apoptosis, necroptosis, autophagy, or other death pathways. Table 2 lists some examples of genes encoded by viruses especially OVs that can intervene apoptosis, autophagy, or necroptosis. The presence of these types of viral genes may skew the mode of infected cancer cells from one to another cell death pathway(s). OVs can be engineered genetically with deletion or insertion of such genes so that a desired mode of ICD would happen in the virus-infected cancer cells.

\section{CANCER CELLS OFTEN SHOW DEFECTS IN CERTAIN CELL DEATH PATHWAYS}

Every cell in a multicellular organism has the potential to die by apoptosis. However, cancer cells often have faulty apoptotic signaling pathways evolved during carcinogenesis. This property derives from the overexpression of anti-apoptotic genes, deficiency of proapoptotic genes, or both (121). These defects not only increase tumor mass, but also render the cancer resistant to therapy.

Evidence has also been accumulating that necroptosis can be impaired in cancer cells. Chronic lymphocytic leukemia cells have defects in signaling pathways involved in necroptosis regulation such as RIP3 and the deubiquitination cylindromatosis (CYLD), an enzyme directly regulating RIP1 ubiquitination (122). Skin cancer cells contain an inactivating CYLD mutation (123). Despite the fact some cancers are resistant to necroptosis due to genetic and epigenetic defects, necroptosis undoubtedly represents an important death pathway induced by many anticancer regimens, particularly important to those cancer resistant to apoptosis. In this case, investigators have found that some compounds can circumvent cancer drug resistance by induction of a necroptotic death (124).

The fact that cancer cells resist certain death pathways will dictate to a degree which types of drugs (including OVs) to be used in therapeutic regimens. As we stated before, a number of OVs, such as VVs, often induces cancer cells into necroptotic cell death $(54,56,57)$, while other viruses such as oncolytic Ad often induce cancer cells into autophagic cell death. Appropriate OVs can be picked depending on the sensitivity of the cancer to certain death pathways, and the immunogenic consequence if it is combined for immunotherapy. 
Table 2 | Examples of viruses and viral genes modulating apoptosis, autophagy, and necroptosis.

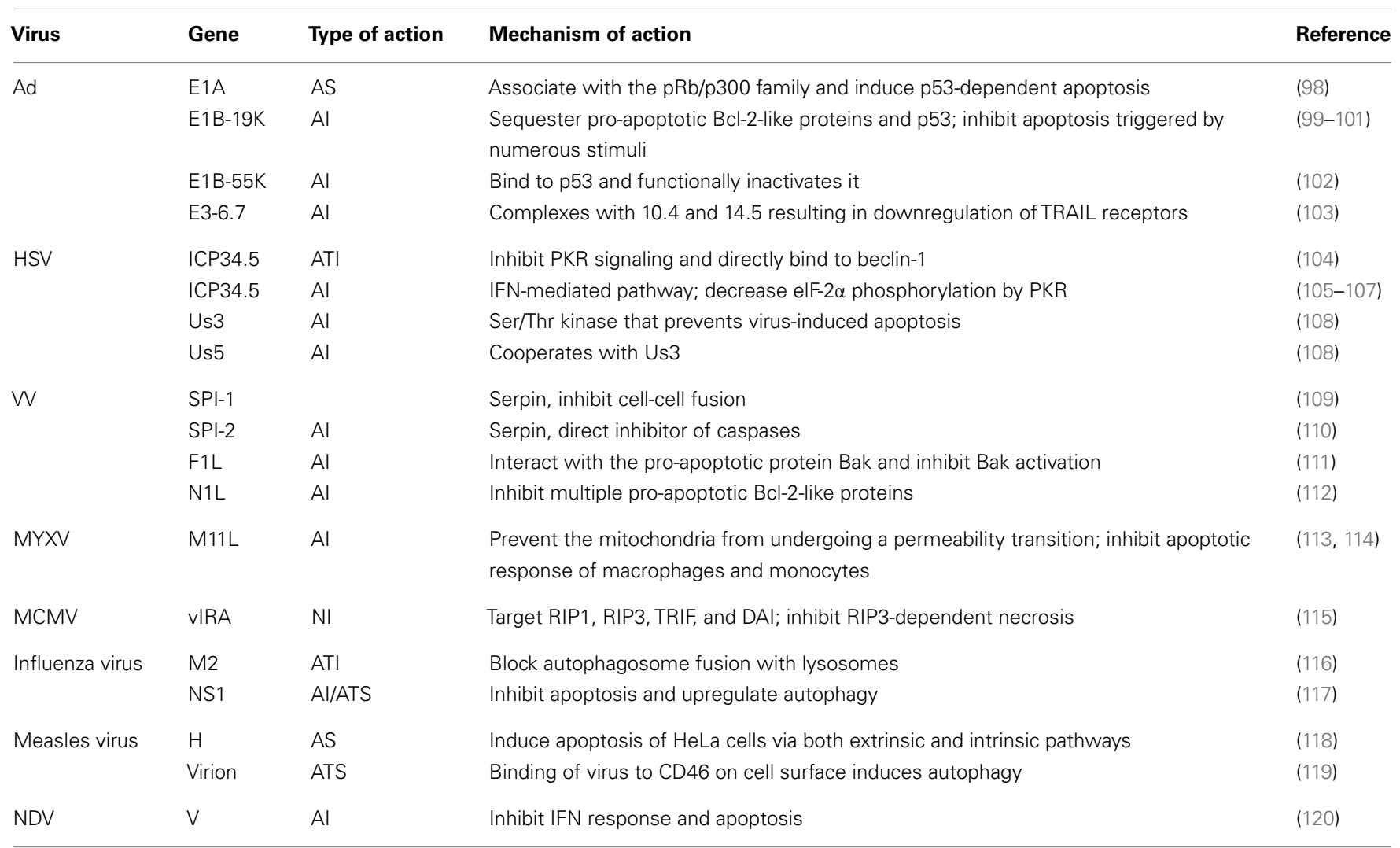

Al, apoptosis inhibitor; AS, apoptosis stimulator; NI, necroptosis inhibitor; ATI, autophagy inhibitor; ATS, autophagy stimulator.

\section{STRATEGIES TO MODULATE THE MODE OF CANCER CELL DEATH FOR ENHANCED IMMUNOGENICITY}

We know now that immunogenic apoptosis, necrosis/necroptosis, and autophagic cell death are desired modes of cancer cell death because they are ICD. Is immunogenic apoptosis (the original form of ICD) better than other forms of ICD in the induction of antitumor immunity? We do not know for sure. This question needs to be addressed in the future. What we do know now is that there are strategies that can enhance the ICD and subsequent antitumor immunity. They can be classified into, genetic modification of OV vectors, combination with ICD inducers, and combination with specific immunostimulatory regimens.

\section{GENETIC ENGINEERING OF VIRAL VECTORS}

Cancer cells have usually accumulated a number of genetic mutations and epigenetic modifications that enable them to resist apoptosis. Based on this property, a number of OVs are built for high tumor selectivity by deleting viral genes encoding antiapoptotic genes (see Table 2 ). These viruses can replicate in cancer cells but lead to rapid apoptosis in normal cells. For examples, the $\gamma 34.5$ gene has been deleted in many oncolytic HSVs, including the T-VEC that is going through a successful phase III clinical trial (125). The adenoviral protein E1B-19K is a Bcl-2 homolog that blocks apoptosis induction via the intrinsic and extrinsic pathways, specifically including tumor necrosis factor (TNF)-mediated cell death. Liu et al. have demonstrated that an E1B-19K gene deletion mutant had TNF-enhanced cancer selectivity due to genetic blocks in apoptosis pathways in cancer cells (126). Similarly, a tumorselective oncolytic vaccinia virus was constructed by deleting two serpin genes, SPI-1 and SPI-2 (54). Due to the deletion of viral antiapoptosis genes, these mutant OVs display more potent oncolysis through apoptosis pathways when combined with appropriate apoptosis-inducing agents.

We believe that by arming OVs with necrosis and autophagypromoting genes, it is possible that the desired cell death pathway can be activated in cancer cells when infected with such OVs, leading to more ICD. More future studies with this strategy are warranted.

\section{COMBINATION WITH ICD INDUCER OR AUTOPHAGY INDUCER}

In theory, $\mathrm{OV}$ in combination with an ICD inducer would provide more potent danger signals to DCs and potentially elicit stronger antitumor immunity. Workenhe et al. demonstrated in a recent study that such a strategy worked well indeed (127). HSV-1 ICP0 null oncolytic vectors possess antitumor activity, but the virus alone is insufficient to break immune tolerance. Thus, the authors hypothesized that combination therapy with an ICD-inducing chemotherapeutic drug might get the job done. Indeed, the combination of HSV-1 ICP0 null oncolytic virus with mitoxantrone, which induces ICD, provided significant survival benefit to the Balb/C mice bearing Her2/neu TUBO-derived mammary tumors. Increased infiltration of neutrophils and tumor 
antigen-specific $\mathrm{CD} 8^{+} \mathrm{T}$ cells into tumor tissues provide the protection, as depletion studies verified that CD8-, CD4-, and Ly6Gexpressing cells are essential for the enhanced efficacy. Importantly, the combination therapy broke immune tolerance. In conclusion, this study suggests that such a combination can enhance the tumor immunogenicity, breaking immunologic tolerance established toward the tumor antigens, thus a promising novel strategy for cancer therapy (127).

As we stated earlier, the autophagy in antigen donor cells (cancer cells) promotes the cross-presentation of antigens from DCs to $\mathrm{T}$ cells. The autophagy could be induced by some OVs, or its inducer could be provided in trans. This strategy works in combination with oncolytic adenoviruses that induce autophagy by themselves $(60,128)$. However, it may not work with an oncolytic vaccinia virus that does not induce autophagy by itself (our unpublished data).

\section{ARMED VIRUS AND COMBINATION STRATEGIES FOR BREAKING IMMUNE TOLERANCE AND ENHANCING ANTITUMOR IMMUNITY}

In order to further enhance the antitumor immunity, OVs have been armed with TAAs, cytokines (e.g., GM-CSF), chemokines (such as CCL5), or other innovative and artificial genes. We have recently reviewed the promising strategies of OVs in combination with other immunotherapeutic regimens (44). As we mentioned, two OVs in the most advanced stages of clinical trials, T-VEC, and Pexa-Vec, are HSV and VV armed with GM-CSF $(125,129)$. An oncolytic VV expressing the 4-1BBL T cell costimulatory molecule (rV-4-1BBL) showed modest tumor regression in the poorly immunogenic B16 murine melanoma model. However, rV-4-1BBL injection with lymphodepletion promoted viral persistence by reducing antiviral antibody titers, and promoted MHC class I expression, and rescued effector-memory $\mathrm{CD} 8^{+} \mathrm{T}$ cells. This significantly improved the therapeutic effectiveness of the oncolytic virus (130). Similarly, an unarmed oncolytic virus combined with anti-4-1BB agonist antibody elicits strong antitumor immunity against established cancer (56). We have also shown that the chemokine CCL5-expressing oncolytic VV in combination with a cancer vaccine or activated $\mathrm{T}$ cells resulted in better therapeutic effect in a MC38 colon cancer model (131). Recently, our collaborators have made an oncolytic VV encoding a secretory bispecific $\mathrm{T}$ cell engager consisting of two single-chain variable fragments specific for $\mathrm{CD} 3$ and the tumor cell surface antigen EphA2 [EphA2-T cell engager-armed VV (EphA2-TEAVV)] (132). This virus retains its normal oncolytic potency and the secreted molecule also activates $\mathrm{T}$ cells. The virus plus $\mathrm{T}$ cells had potent antitumor activity in a lung cancer xenograft model. Thus, arming oncolytic VVs with T cell engagers may represent a promising approach to improve oncolytic virotherapy. In the context of OV-mediated cancer immunotherapy, it is interesting to observe the dual effects of antiviral immunity on cancer therapy. On one hand, the antiviral immunity may attenuate the replication of an OV and thus diminish the effect of direct oncolysis; on the other hand, antiviral immunity plays a key role for the therapeutic success of oncolytic virotherapy in some cases $(11,133)$.

The tumor-associated immune tolerance is a big obstacle in cancer immunotherapy. Some armed OVs (such as a GM-CSFarmed oncolytic Ad) can break immune tolerance and generated antitumor immunity in at least some human cancer patients (134). In other cases, an OV alone is not enough to break the immune tolerance in highly immunosuppressive TME (127). In these cases, a combination with an ICD-inducing chemotherapeutic drug may break the immune tolerance (127). Alternatively, an OV can be combined with an immune checkpoint inhibitor to achieve the same effect. During the preparation of this review, a study has just been published on such a strategy with oncolytic NDV and systemic CTLA-4 blockade. This combination led to rejection of pre-established distant tumors and protection from tumor rechallenge in poorly immunogenic tumor models (74). It showcases the promise of such a combination strategy.

\section{CONCLUSION AND PERSPECTIVES}

The TME in the advanced stage of disease is highly immunosuppressive (18). This immunological property is a double-edged sword for OV-mediated cancer therapy: good for viral replication but bad for the antitumor immunity. The evidence is accumulating that OVs not only kill infected cancer cells and associated endothelial cells by direct and indirect oncolysis, but also release/present danger signals to DCs and other professional APCs to elicit both antiviral and antitumor immunity. It has been demonstrated for a number of OVs, that the virus-elicited antitumor immunity plays a critical role in the overall efficacy of oncolytic virotherapy. As we and other colleagues have realized, ICD is important to elicit antitumor immunity $(44,45,135)$.

In order to improve the potency of antitumor immunity, one key step is the initial presentation of danger signal (signal 0) and cross-presentation of TAAs (signal 1). Recent studies demonstrated that ICD of cancer cells leads to potent danger signals, and autophagy in antigen donor cells, in this case cancer cells and associated endothelial cells, enhance the cross-presentation of TAAs to naïve T cells by DCs. Genetic engineering and combination strategies can skew the cancer cell death into modes of ICD and autophagy, leading to potent and sustained antitumor immunity and thus enhancing the efficacy of oncolytic immunotherapy. Which mode of ICD in the context of OVs is the most potent way to elicit antitumor immunity needs careful investigation in the near future. It is also important to keep in mind that oncolytic viruses modulate cancer immunogenicity through multiple mechanisms (136). Other than the induced danger signals, they are out of the scope of this review article and thus have not been discussed. Finally, we and others believe that it is important to further test the idea that combination of OV with blockade of immune checkpoints for potent and sustained antitumor immunity would enhance this novel form of immunotherapy for cancer. We look forward to more exciting development of both preclinical and clinical studies with OVs as tools for cancer immunotherapy.

\section{AUTHOR CONTRIBUTIONS}

Zong Sheng Guo collected and read relevant papers; designed and drafted the manuscript. David L. Bartlett and Zuqiang Liu have made suggestions to the manuscript. All authors have read and approved the final manuscript.

\section{ACKNOWLEDGMENTS}

This work has been supported by the grants P01CA132714 and R01CA155925 from the National Institutes of Health. Additional 
Support was provided by David C. Koch Regional Therapy Cancer Center. We would like to thank Ms. Roshni Ravindranathan for critical reading and comments on the manuscript.

\section{REFERENCES}

1. Russell SJ, Peng KW, Bell JC. Oncolytic virotherapy. Nat Biotechnol (2012) 30:658-70. doi:10.1038/nbt.2287

2. Patel MR, Kratzke RA. Oncolytic virus therapy for cancer: the first wave of translational clinical trials. Transl Res (2013) 161:355-64. doi:10.1016/j.trsl. 2012.12.010

3. Guo ZS, Thorne SH, Bartlett DL. Oncolytic virotherapy: molecular targets in tumor-selective replication and carrier cell-mediated delivery of oncolytic viruses. Biochim Biophys Acta (2008) 1785:217-31. doi:10.1016/j.bbcan.2008. 02.001

4. Breitbach CJ, Paterson JM, Lemay CG, Falls TJ, McGuire A, Parato KA, et al. Targeted inflammation during oncolytic virus therapy severely compromises tumor blood flow. Mol Ther (2007) 15:1686-93. doi:10.1038/sj.mt.6300215

5. Liu TC, Hwang T, Park BH, Bell J, Kirn DH. The targeted oncolytic poxvirus JX594 demonstrates antitumoral, antivascular, and anti-HBV activities in patients with hepatocellular carcinoma. Mol Ther (2008) 16:1637-42. doi:10.1038/mt. 2008.143

6. Breitbach CJ, Arulanandam R, De Silva N, Thorne SH, Patt R, Daneshmand $\mathrm{M}$, et al. Oncolytic vaccinia virus disrupts tumor-associated vasculature in humans. Cancer Res (2013) 73:1265-75. doi:10.1158/0008-5472.CAN-122687

7. Diaz RM, Galivo F, Kottke T, Wongthida P, Qiao J, Thompson J, et al. Oncolytic immunovirotherapy for melanoma using vesicular stomatitis virus. Cancer Res (2007) 67:2840-8. doi:10.1158/0008-5472.CAN-06-3974

8. Prestwich RJ, Errington F, Ilett EJ, Morgan RS, Scott KJ, Kottke T, et al. Tumor infection by oncolytic reovirus primes adaptive antitumor immunity. Clin Cancer Res (2008) 14:7358-66. doi:10.1158/1078-0432.CCR-08-0831

9. Prestwich RJ, Ilett EJ, Errington F, Diaz RM, Steele LP, Kottke T, et al. Immunemediated antitumor activity of reovirus is required for therapy and is independent of direct viral oncolysis and replication. Clin Cancer Res (2009) 15:4374-81. doi:10.1158/1078-0432.CCR-09-0334

10. Wongthida P, Diaz RM, Galivo F, Kottke T, Thompson J, Pulido J, et al. Type III IFN interleukin-28 mediates the antitumor efficacy of oncolytic virus VSV in immune-competent mouse models of cancer. Cancer Res (2010) 70:4539-49. doi:10.1158/0008-5472.CAN-09-4658

11. Sobol PT, Boudreau JE, Stephenson K, Wan Y, Lichty BD, Mossman KL. Adaptive antiviral immunity is a determinant of the therapeutic success of oncolytic virotherapy. Mol Ther (2011) 19:335-44. doi:10.1038/mt.2010.264

12. Diaconu I, Cerullo V, Hirvinen ML, Escutenaire S, Ugolini M, Pesonen SK, et al. Immune response is an important aspect of the antitumor effect produced by a CD40L-encoding oncolytic adenovirus. Cancer Res (2012) 72:2327-38. doi:10.1158/0008-5472.CAN-11-2975

13. Huang PY, Guo JH, Hwang LH. Oncolytic Sindbis virus targets tumors defective in the interferon response and induces significant bystander antitumor immunity in vivo. Mol Ther (2012) 20:298-305. doi:10.1038/mt.2011.245

14. Workenhe ST, Simmons G, Pol JG, Lichty BD, Halford WP, Mossman KL. Immunogenic HSV-mediated oncolysis shapes the antitumor immune response and contributes to therapeutic efficacy. Mol Ther (2014) 22:123-31. doi:10.1038/mt.2013.238

15. Matzinger P. The danger model: a renewed sense of self. Science (2002) 296:301-5. doi:10.1126/science.1071059

16. Medzhitov R, Janeway CA Jr. Decoding the patterns of self and nonself by the innate immune system. Science (2002) 296:298-300. doi:10.1126/science. 1068883

17. Tang D, Kang R, Coyne CB, Zeh HJ, Lotze MT. PAMPs and DAMPs: signal 0s that spur autophagy and immunity. Immunol Rev (2012) 249:158-75. doi:10.1111/j.1600-065X.2012.01146.x

18. Zou W. Immunosuppressive networks in the tumour environment and their therapeutic relevance. Nat Rev Cancer (2005) 5:263-74. doi:10.1038/nrc1586

19. Naik S, Russell SJ. Engineering oncolytic viruses to exploit tumor specific defects in innate immune signaling pathways. Expert Opin Biol Ther (2009) 9:1163-76. doi:10.1517/14712590903170653
20. Kim M, Williamson CT, Prudhomme J, Bebb DG, Riabowol K, Lee PW, et al. The viral tropism of two distinct oncolytic viruses, reovirus and myxoma virus, is modulated by cellular tumor suppressor gene status. Oncogene (2010) 29:3990-6. doi:10.1038/onc.2010.137

21. Young AM, Archibald KM, Tookman LA, Pool A, Dudek K, Jones C, et al. Failure of translation of human adenovirus mRNA in murine cancer cells can be partially overcome by L4-100K expression in vitro and in vivo. Mol Ther (2012) 20:1676-88. doi:10.1038/mt.2012.116

22. Janeway C. Immunogenicity signals $1,2,3 \ldots$ and 0 . Immunol Today (1989) 10:283-6. doi:10.1016/0167-5699(89)90081-9

23. Janeway CA Jr. Approaching the asymptote? Evolution and revolution in immunology. Cold Spring Harb Symp Quant Biol (1989) 54(Pt 1):1-13. doi:10.1101/SQB.1989.054.01.003

24. Janeway CA Jr, Medzhitov R. Innate immune recognition. Annu Rev Immunol (2002) 20:197-216. doi:10.1146/annurev.immunol.20.083001.084359

25. Bianchi ME. DAMPs, PAMPs and alarmins: all we need to know about danger. J Leukoc Biol (2007) 81:1-5. doi:10.1189/jlb.0306164

26. Tapia K, Kim WK, Sun Y, Mercado-López X, Dunay E, Wise M, et al. Defective viral genomes arising in vivo provide critical danger signals for the triggering of lung antiviral immunity. PLoS Pathog (2013) 9:e1003703. doi:10.1371/journal.ppat.1003703

27. Takeuchi O, Akira S. Pattern recognition receptors and inflammation. Cell (2010) 140:805-20. doi:10.1016/j.cell.2010.01.022

28. Joffre O, Nolte MA, Sporri R, Reis e Sousa C. Inflammatory signals in dendritic cell activation and the induction of adaptive immunity. Immunol Rev (2009) 227:234-47. doi:10.1111/j.1600-065X.2008.00718.x

29. Zanoni I, Granucci F. Regulation of antigen uptake, migration, and lifespan of dendritic cell by toll-like receptors. J Mol Med (Berl) (2010) 88:873-80. doi:10.1007/s00109-010-0638-x

30. Matzinger P. Tolerance, danger, and the extended family. Annu Rev Immunol (1994) 12:991-1045. doi:10.1146/annurev.immunol.12.1.991

31. Kono H, Rock KL. How dying cells alert the immune system to danger. Nat Rev Immunol (2008) 8:279-89. doi:10.1038/nri2215

32. Shi Y, Evans JE, Rock KL. Molecular identification of a danger signal that alerts the immune system to dying cells. Nature (2003) 425:516-21. doi:10.1038/ nature01991

33. Scheibner KA, Lutz MA, Boodoo S, Fenton MJ, Powell JD, Horton MR. Hyaluronan fragments act as an endogenous danger signal by engaging TLR2. J Immunol (2006) 177:1272-81.

34. Klune JR, Dhupar R, Cardinal J, Billiar TR, Tsung A. HMGB1: endogenous danger signaling. Mol Med (2008) 14:476-84. doi:10.2119/2008-00034.Klune

35. Guo ZS, Liu Z, Bartlett DL, Tang D, Lotze MT. Life after death: targeting high mobility group box 1 in emergent cancer therapies. Am J Cancer Res (2013) 3:1-20.

36. Krysko DV, Agostinis P, Krysko O, Garg AD, Bachert C, Lambrecht BN, et al. Emerging role of damage-associated molecular patterns derived from mitochondria in inflammation. Trends Immunol (2011) 32:157-64. doi:10.1016/j. it.2011.01.005

37. Krysko DV, Garg AD, Kaczmarek A, Krysko O, Agostinis P, Vandenabeele P. Immunogenic cell death and DAMPs in cancer therapy. Nat Rev Cancer (2012) 12:860-75. doi:10.1038/nrc3380

38. Casares N, Pequignot MO, Tesniere A, Ghiringhelli F, Roux S, Chaput N, et al. Caspase-dependent immunogenicity of doxorubicin-induced tumor cell death. J Exp Med (2005) 202:1691-701. doi:10.1084/jem.20050915

39. Lindenmann J, Klein PA. Viral oncolysis: increased immunogenicity of host cell antigen associated with influenza virus. J Exp Med (1967) 126:93-108. doi:10.1084/jem.126.1.93

40. Melcher A, Todryk S, Hardwick N, Ford M, Jacobson M, Vile RG. Tumor immunogenicity is determined by the mechanism of cell death via induction of heat shock protein expression. Nat Med (1998) 4:581-7. doi:10.1038/ nm0598-581

41. Obeid M, Tesniere A, Ghiringhelli F, Fimia GM, Apetoh L, Perfettini JL, et al. Calreticulin exposure dictates the immunogenicity of cancer cell death. Nat Med (2007) 13:54-61. doi:10.1038/nm1523

42. Tesniere A, Apetoh L, Ghiringhelli F, Joza N, Panaretakis T, Kepp O, et al. Immunogenic cancer cell death: a key-lock paradigm. Curr Opin Immunol (2008) 20:504-11. doi:10.1016/j.coi.2008.05.007 
43. Green DR, Ferguson T, Zitvogel L, Kroemer G. Immunogenic and tolerogenic cell death. Nat Rev Immunol (2009) 9:353-63. doi:10.1038/nri2545

44. Bartlett DL, Liu Z, Sathaiah M, Ravindranathan R, Guo Z, He Y, et al. Oncolytic viruses as therapeutic cancer vaccines. Mol Cancer (2013) 12:103. doi:10.1186/1476-4598-12-103

45. Inoue H, Tani K. Multimodal immunogenic cancer cell death as a consequence of anticancer cytotoxic treatments. Cell Death Differ (2014) 21:39-49. doi:10.1038/cdd.2013.84

46. Tesniere A, Panaretakis T, Kepp O, Apetoh L, Ghiringhelli F, Zitvogel L, et al. Molecular characteristics of immunogenic cancer cell death. Cell Death Differ (2008) 15:3-12. doi:10.1038/sj.cdd.4402269

47. Lamkanfi M, Dixit VM. Manipulation of host cell death pathways during microbial infections. Cell Host Microbe (2010) 8:44-54. doi:10.1016/j.chom. 2010.06.007

48. Ito H, Aoki H, Kühnel F, Kondo Y, Kubicka S, Wirth T, et al. Autophagic cell death of malignant glioma cells induced by a conditionally replicating adenovirus. J Natl Cancer Inst (2006) 98:625-36. doi:10.1093/jnci/djj161

49. Alonso MM, Jiang H, Yokoyama T, Xu J, Bekele NB, Lang FF, et al. Delta-24RGD in combination with RAD001 induces enhanced anti-glioma effect via autophagic cell death. Mol Ther (2008) 16:487-93. doi:10.1038/sj.mt.6300400

50. Baird SK, Aerts JL, Eddaoudi A, Lockley M, Lemoine NR, McNeish IA. Oncolytic adenoviral mutants induce a novel mode of programmed cell death in ovarian cancer. Oncogene (2008) 27:3081-90. doi:10.1038/sj.onc.1210977

51. Rodriguez-Rocha H, Gomez-Gutierrez JG, Garcia-Garcia A, Rao XM, Chen L, McMasters KM, et al. Adenoviruses induce autophagy to promote virus replication and oncolysis. Virology (2011) 416:9-15. doi:10.1016/j.virol.2011. 04.017

52. Miyamoto S, Inoue H, Nakamura T, Yamada M, Sakamoto C, Urata Y, et al. Coxsackievirus B3 is an oncolytic virus with immunostimulatory properties that is active against lung adenocarcinoma. Cancer Res (2012) 72:2609-21. doi:10.1158/0008-5472.CAN-11-3185

53. Donnelly OG, Errington-Mais F, Steele L, Hadac E, Jennings V, Scott K, et al. Measles virus causes immunogenic cell death in human melanoma. Gene Ther (2013) 20:7-15. doi:10.1038/gt.2011.205

54. Guo ZS, Naik A, O’Malley ME, Popovic P, Demarco R, Hu Y, et al. The enhanced tumor selectivity of an oncolytic vaccinia lacking the host range and antiapoptosis genes SPI-1 and SPI-2. Cancer Res (2005) 65:9991-8. doi:10.1158/0008-5472.CAN-05-1630

55. Huang B, Sikorski R, Kirn DH, Thorne SH. Synergistic anti-tumor effects between oncolytic vaccinia virus and paclitaxel are mediated by the IFN response and HMGB1. Gene Ther (2011) 18:164-72. doi:10.1038/gt.2010.121

56. John LB, Howland LJ, Flynn JK, West AC, Devaud C, Duong CP, et al. Oncolytic virus and anti-4-1BB combination therapy elicits strong antitumor immunity against established cancer. Cancer Res (2012) 72:1651-60. doi:10.1158/0008-5472.CAN-11-2788

57. Whilding LM, Archibald KM, Kulbe H, Balkwill FR, Öberg D, McNeish IA. Vaccinia virus induces programmed necrosis in ovarian cancer cells. Mol Ther (2013) 21:2074-86. doi:10.1038/mt.2013.195

58. Borde C, Barnay-Verdier S, Gaillard C, Hocini H, Maréchal V, Gozlan J. Stepwise release of biologically active HMGB1 during HSV-2 infection. PLoS One (2011) 6:e16145. doi:10.1371/journal.pone.0016145

59. Angelova AL, Grekova SP, Heller A, Kuhlmann O, Soyka E, Giese T, et al. Complementary induction of immunogenic cell death by oncolytic parvovirus $\mathrm{H}$ $1 \mathrm{PV}$ and gemcitabine in pancreatic cancer. J Virol (2014). doi:10.1128/JVI. 03688-13

60. Liikanen I, Ahtiainen L, Hirvinen ML, Bramante S, Cerullo V, Nokisalmi P, et al. Oncolytic adenovirus with temozolomide induces autophagy and antitumor immune responses in cancer patients. Mol Ther (2013) 21:1212-23. doi:10.1038/mt.2013.51

61. Endo Y, Sakai R, Ouchi M, Onimatsu H, Hioki M, Kagawa S, et al. Virus-mediated oncolysis induces danger signal and stimulates cytotoxic Tlymphocyte activity via proteasome activator upregulation. Oncogene (2008) 27:2375-81. doi:10.1038/sj.onc. 1210884

62. Colunga AG, Laing JM, Aurelian L. The HSV-2 mutant DeltaPK induces melanoma oncolysis through nonredundant death programs and associated with autophagy and pyroptosis proteins. Gene Ther (2010) 17:315-27. doi:10.1038/gt.2009.126
63. Wang Q, Imamura R, Motani K, Kushiyama H, Nagata S, Suda T. Pyroptotic cells externalize eat-me and release find-me signals and are efficiently engulfed by macrophages. Int Immunol (2013) 25:363-72. doi:10.1093/ intimm/dxs161

64. Ito N, DeMarco RA, Mailliard RB, Han J, Rabinowich H, Kalinski P, et al. Cytolytic cells induce HMGB1 release from melanoma cell lines. J Leukoc Biol (2007) 81:75-83. doi:10.1189/jlb.0306169

65. Moehler M, Zeidler M, Schede J, Rommelaere J, Galle PR, Cornelis JJ, et al. Oncolytic parvovirus $\mathrm{H} 1$ induces release of heat-shock protein HSP72 in susceptible human tumor cells but may not affect primary immune cells. Cancer Gene Ther (2003) 10:477-80. doi:10.1038/sj.cgt.7700591

66. Grekova S, Aprahamian M, Giese N, Schmitt S, Giese T, Falk CS, et al. Immune cells participate in the oncosuppressive activity of parvovirus $\mathrm{H}-1 \mathrm{PV}$ and are activated as a result of their abortive infection with this agent. Cancer Biol Ther (2010) 10:1280-9. doi:10.4161/cbt.10.12.13455

67. Grekova SP, Raykov Z, Zawatzky R, Rommelaere J, Koch U. Activation of a glioma-specific immune response by oncolytic parvovirus minute virus of mice infection. Cancer Gene Ther (2012) 19:468-75. doi:10.1038/cgt.2012.20

68. Radic M, Marion T, Monestier M. Nucleosomes are exposed at the cell surface in apoptosis. J Immunol (2004) 172:6692-700.

69. Uratsuji H, Tada Y, Kawashima T, Kamata M, Hau CS, Asano Y, et al. P2Y6 receptor signaling pathway mediates inflammatory responses induced by monosodium urate crystals. J Immunol (2012) 188:436-44. doi:10.4049/ jimmunol.1003746

70. Elankumaran S, Rockemann D, Samal SK. Newcastle disease virus exerts oncolysis by both intrinsic and extrinsic caspase-dependent pathways of cell death. J Virol (2006) 80:7522-34. doi:10.1128/JVI.00241-06

71. Meng C, Zhou Z, Jiang K, Yu S, Jia L, Wu Y, et al. Newcastle disease virus triggers autophagy in U251 glioma cells to enhance virus replication. Arch Virol (2012) 157:1011-8. doi:10.1007/s00705-012-1270-6

72. Washburn B, Schirrmacher V. Human tumor cell infection by Newcastle disease virus leads to upregulation of HLA and cell adhesion molecules and to induction of interferons, chemokines and finally apoptosis. Int J Oncol (2002) 21:85-93. doi:10.3892/ijo.21.1.85

73. Fournier P, Arnold A, Wilden H, Schirrmacher V. Newcastle disease virus induces pro-inflammatory conditions and type I interferon for counter-acting Treg activity. Int J Oncol (2012) 40:840-50. doi:10.3892/ijo.2011.1265

74. Zamarin D, Holmgaard RB, Subudhi SK, Park JS, Mansour M, Palese P, et al. Localized oncolytic virotherapy overcomes systemic tumor resistance to immune checkpoint blockade immunotherapy. Sci Transl Med (2014) 6:226-32. doi:10.1126/scitranslmed.3008095

75. Errington F, Steele L, Prestwich R, Harrington KJ, Pandha HS, Vidal L, et al. Reovirus activates human dendritic cells to promote innate antitumor immunity. J Immunol (2008) 180:6018-26.

76. Fournier P, Schirrmacher V. Oncolytic Newcastle disease virus as cutting edge between tumor and host. Biology (2013) 2:936-75. doi:10.3390/ biology2030936

77. Clarke P, Meintzer SM, Gibson S, Widmann C, Garrington TP, Johnson GL, et al. Reovirus-induced apoptosis is mediated by TRAIL. J Virol (2000) 74:8135-9. doi:10.1128/JVI.74.17.8135-8139.2000

78. Berger AK, Danthi P. Reovirus activates a caspase-independent cell death pathway. MBio (2013) 4:e178-113. doi:10.1128/mBio.00178-13

79. Chi PI, Huang WR, Lai IH, Cheng CY, Liu HJ. The p17 nonstructural protein of avian reovirus triggers autophagy enhancing virus replication via activation of phosphatase and tensin deleted on chromosome 10 (PTEN) and AMP-activated protein kinase (AMPK), as well as dsRNA-dependent protein kinase (PKR)/eIF2alpha signaling pathways. J Biol Chem (2012) 288:3571-84 doi:10.1074/jbc.M112.390245

80. Meng S, Jiang K, Zhang X, Zhang M, Zhou Z, Hu M, et al. Avian reovirus triggers autophagy in primary chicken fibroblast cells and Vero cells to promote virus production. Arch Virol (2012) 157:661-8. doi:10.1007/s00705-012-1226-x

81. Thirukkumaran CM, Shi ZQ, Luider J, Kopciuk K, Gao H, Bahlis N, et al. Reovirus modulates autophagy during oncolysis of multiple myeloma. Autophagy (2013) 9:413-4. doi:10.4161/auto.22867

82. Errington F, White CL, Twigger KR, Rose A, Scott K, Steele L, et al. Inflammatory tumour cell killing by oncolytic reovirus for the treatment of melanoma. Gene Ther (2008) 15:1257-70. doi:10.1038/gt.2008.58 
83. Levine B, Deretic V. Unveiling the roles of autophagy in innate and adaptive immunity. Nat Rev Immunol (2007) 7:767-77. doi:10.1038/nri2161

84. Chakrabarti A, Ghosh PK, Banerjee S, Gaughan C, Silverman RH. RNase L triggers autophagy in response to viral infections. J Virol (2012) 86:11311-21. doi:10.1128/JVI.00270-12

85. English L, Chemali M, Duron J, Rondeau C, Laplante A, Gingras D, et al. Autophagy enhances the presentation of endogenous viral antigens on $\mathrm{MHC}$ class I molecules during HSV-1 infection. Nat Immunol (2009) 10:480-7. doi:10.1038/ni.1720

86. Alexander DE, Ward SL, Mizushima N, Levine B, Leib DA. Analysis of the role of autophagy in replication of herpes simplex virus in cell culture. $J$ Virol (2007) 81:12128-34. doi:10.1128/JVI.01356-07

87. Comber JD, Robinson TM, Siciliano NA, Snook AE, Eisenlohr LC. Functional macroautophagy induction by influenza A virus without a contribution to major histocompatibility complex class II-restricted presentation. J Virol (2010) 85:6453-63. doi:10.1128/JVI.02122-10

88. Michaud M, Martins I, Sukkurwala AQ, Adjemian S, Ma Y, Pellegatti $\mathrm{P}$, et al. Autophagy-dependent anticancer immune responses induced by chemotherapeutic agents in mice. Science (2011) 334:1573-7. doi:10.1126/ science. 1208347

89. Ayna G, Krysko DV, Kaczmarek A, Petrovski G, Vandenabeele P, Fésüs L. ATP release from dying autophagic cells and their phagocytosis are crucial for inflammasome activation in macrophages. PLoS One (2012) 7:e40069. doi:10.1371/journal.pone.0040069

90. Thorburn J, Horita H, Redzic J, Hansen K, Frankel AE, Thorburn A. Autophagy regulates selective HMGB1 release in tumor cells that are destined to die. Cell Death Differ (2009) 16:175-83. doi:10.1038/cdd.2008.143

91. Dengjel J, Schoor O, Fischer R, Reich M, Kraus M, Müller M, et al. Autophagy promotes MHC class II presentation of peptides from intracellular source proteins. Proc Natl Acad Sci U S A (2005) 102:7922-7. doi:10.1073/pnas. 0501190102

92. Li Y, Wang LX, Yang G, Hao F, Urba WJ, Hu HM. Efficient cross-presentation depends on autophagy in tumor cells. Cancer Res (2008) 68:6889-95. doi:10. 1158/0008-5472.CAN-08-0161

93. Wei J, Waithman J, Lata R, Mifsud NA, Cebon J, Kay T, et al. Influenza A infection enhances cross-priming of CD8 $+\mathrm{T}$ cells to cell-associated antigens in a TLR7- and type I IFN-dependent fashion. J Immunol (2010) 185:6013-22. doi:10.4049/jimmunol.1002129

94. Gauvrit A, Brandler S, Sapede-Peroz C, Boisgerault N, Tangy F, Gregoire M. Measles virus induces oncolysis of mesothelioma cells and allows dendritic cells to cross-prime tumor-specific CD8 response. Cancer Res (2008) 68:4882-92. doi:10.1158/0008-5472.CAN-07-6265

95. Uhl M, Kepp O, Jusforgues-Saklani H, Vicencio JM, Kroemer G, Albert ML. Autophagy within the antigen donor cell facilitates efficient antigen crosspriming of virus-specific CD8+ T cells. Cell Death Differ (2009) 16:991-1005. doi:10.1038/cdd.2009.8

96. Li Y, Wang LX, Pang P, Cui Z, Aung S, Haley D, et al. Tumor-derived autophagosome vaccine: mechanism of cross-presentation and therapeutic efficacy. Clin Cancer Res (2011) 17:7047-57. doi:10.1158/1078-0432.CCR-11-0951

97. Meng S, Xu J, Wu Y, Ding C. Targeting autophagy to enhance oncolytic virusbased cancer therapy. Expert Opin Biol Ther (2013) 13:863-73. doi:10.1517/ 14712598.2013.774365

98. Lowe SW, Ruley HE. Stabilization of the p53 tumor suppressor is induced by adenovirus 5 E1A and accompanies apoptosis. Genes Dev (1993) 7:535-45. doi:10.1101/gad.7.4.535

99. Debbas M, White E. Wild-type p53 mediates apoptosis by E1A, which is inhibited by E1B. Genes Dev (1993) 7:546-54. doi:10.1101/gad.7.4.546

100. Perez D, White E. TNF-alpha signals apoptosis through a bid-dependent conformational change in Bax that is inhibited by E1B 19K. Mol Cell (2000) 6:53-63. doi:10.1016/S1097-2765(00)00007-1

101. White E, Sabbatini P, Debbas M, Wold WS, Kusher DI, Gooding LR. The 19kilodalton adenovirus E1B transforming protein inhibits programmed cell death and prevents cytolysis by tumor necrosis factor alpha. Mol Cell Biol (1992) 12:2570-80.

102. Marcellus RC, Teodoro JG, Charbonneau R, Shore GC, Branton PE. Expression of p53 in Saos-2 osteosarcoma cells induces apoptosis which can be inhibited by Bcl-2 or the adenovirus E1B-55 kDa protein. Cell Growth Differ (1996) 7:1643-50
103. Benedict CA, Norris PS, Prigozy TI, Bodmer JL, Mahr JA, Garnett CT, et al. Three adenovirus E3 proteins cooperate to evade apoptosis by tumor necrosis factor-related apoptosis-inducing ligand receptor-1 and -2. J Biol Chem (2001) 276:3270-8. doi:10.1074/jbc.M008218200

104. Orvedahl A, Alexander D, Tallóczy Z, Sun Q, Wei Y, Zhang W, et al. HSV-1 ICP34.5 confers neurovirulence by targeting the beclin 1 autophagy protein. Cell Host Microbe (2007) 1:23-35. doi:10.1016/j.chom.2006.12.001

105. Cassady KA, Gross M, Roizman B. The second-site mutation in the herpes simplex virus recombinants lacking the gamma134.5 genes precludes shutoff of protein synthesis by blocking the phosphorylation of eIF-2alpha. J Virol (1998) 72:7005-11.

106. Randazzo BP, Tal-Singer R, Zabolotny JM, Kesari S, Fraser NW. Herpes simplex virus 1716, an ICP 34.5 null mutant, is unable to replicate in CV-1 cells due to a translational block that can be overcome by coinfection with SV40. J Gen Virol (1997) 78(Pt 12):3333-9.

107. Chou J, Roizman B. The gamma 1(34.5) gene of herpes simplex virus 1 precludes neuroblastoma cells from triggering total shutoff of protein synthesis characteristic of programed cell death in neuronal cells. Proc Natl Acad Sci US A (1992) 89:3266-70. doi:10.1073/pnas.89.8.3266

108. Jerome KR, Fox R, Chen Z, Sears AE, Lee Hy, Corey L. Herpes simplex virus inhibits apoptosis through the action of two genes, Us5 and Us3. J Virol (1999) 73:8950-7.

109. Zhou J, Sun XY, Fernando GJ, Frazer IH. The vaccinia virus K2L gene encodes a serine protease inhibitor which inhibits cell-cell fusion. Virology (1992) 189:678-86. doi:10.1016/0042-6822(92)90591-C

110. Dobbelstein M, Shenk T. Protection against apoptosis by the vaccinia virus SPI-2 (B13R) gene product. J Virol (1996) 70:6479-85.

111. Wasilenko ST, Banadyga L, Bond D, Barry M. The vaccinia virus F1L protein interacts with the proapoptotic protein Bak and inhibits Bak activation. J Virol (2005) 79:14031-43. doi:10.1128/JVI.79.22.14031-14043.2005

112. Cooray S, Bahar MW, Abrescia NG, McVey CE, Bartlett NW, Chen RA, et al. Functional and structural studies of the vaccinia virus virulence factor N1 reveal a Bcl-2-like anti-apoptotic protein. J Gen Virol (2007) 88:1656-66. doi:10.1099/vir.0.82772-0

113. Everett H, Barry M, Lee SF, Sun X, Graham K, Stone J, et al. M11L: a novel mitochondria-localized protein of myxoma virus that blocks apoptosis of infected leukocytes. J Exp Med (2000) 191:1487-98. doi:10.1084/jem.191.9. 1487

114. Macen JL, Graham KA, Lee SF, Schreiber M, Boshkov LK, McFadden G. Expression of the myxoma virus tumor necrosis factor receptor homologue and M11L genes is required to prevent virus-induced apoptosis in infected rabbit T lymphocytes. Virology (1996) 218:232-7. doi:10.1006/viro.1996.0183

115. Upton JW, Kaiser WJ, Mocarski ES. Virus inhibition of RIP3-dependent necrosis. Cell Host Microbe (2010) 7:302-13. doi:10.1016/j.chom.2010.03.006

116. Gannagé M, Dormann D, Albrecht R, Dengjel J, Torossi T, Rämer PC, et al. Matrix protein 2 of influenza A virus blocks autophagosome fusion with lysosomes. Cell Host Microbe (2009) 6:367-80. doi:10.1016/j.chom.2009.09.005

117. Zhirnov OP, Klenk HD. Influenza A virus proteins NS1 and hemagglutinin along with M2 are involved in stimulation of autophagy in infected cells. J Virol (2013) 87:13107-14. doi:10.1128/JVI.02148-13

118. Yi C, Liu X, Liu Y, Lu S, Qi Y. Hemagglutinin protein of measles virus induces apoptosis of HeLa cells via both extrinsic and intrinsic pathways. Can J Microbiol (2013) 59:814-24. doi:10.1139/cjm-2013-0544

119. Meiffren G, Joubert PE, Grégoire IP, Codogno P, Rabourdin-Combe C, Faure M. Pathogen recognition by the cell surface receptor CD46 induces autophagy. Autophagy (2010) 6:299-300. doi:10.4161/auto.6.2.11132

120. Park MS, García-Sastre A, Cros JF, Basler CF, Palese P. Newcastle disease virus V protein is a determinant of host range restriction. J Virol (2003) 77:9522-32. doi:10.1128/JVI.77.17.9522-9532.2003

121. Igney FH, Krammer PH. Death and anti-death: tumour resistance to apoptosis Nat Rev Cancer (2002) 2:277-88. doi:10.1038/nrc776

122. Liu P, Xu B, Shen W, Zhu H, Wu W, Fu Y, et al. Dysregulation of TNFalphainduced necroptotic signaling in chronic lymphocytic leukemia: suppression of CYLD gene by LEF1. Leukemia (2012) 26:1293-300. doi:10.1038/leu.2011.357

123. Alameda JP, Moreno-Maldonado R, Navarro M, Bravo A, Ramírez A, Page A, et al. An inactivating CYLD mutation promotes skin tumor progression by conferring enhanced proliferative, survival and angiogenic properties to epidermal cancer cells. Oncogene (2010) 29:6522-32. doi:10.1038/onc.2010.378 
124. Han W, Li L, Qiu S, Lu Q, Pan Q, Gu Y, et al. Shikonin circumvents cancer drug resistance by induction of a necroptotic death. Mol Cancer Ther (2007) 6:1641-9. doi:10.1158/1535-7163.MCT-06-0511

125. Kaufman HL, Bines SD. OPTIM trial: a phase III trial of an oncolytic herpes virus encoding GM-CSF for unresectable stage III or IV melanoma. Future Oncol (2010) 6:941-9. doi:10.2217/fon.10.66

126. Liu TC, Hallden G, Wang Y, Brooks G, Francis J, Lemoine N, et al. An E1B-19 $\mathrm{kDa}$ gene deletion mutant adenovirus demonstrates tumor necrosis factorenhanced cancer selectivity and enhanced oncolytic potency. Mol Ther (2004) 9:786-803. doi:10.1016/j.ymthe.2004.03.017

127. Workenhe ST, Pol JG, Lichty BD, Cummings DT, Mossman KL. Combining oncolytic HSV-1 with immunogenic cell death-inducing drug mitoxantrone breaks cancer immune tolerance and improves therapeutic efficacy. Cancer Immunol Res (2013) 1:309-19. doi:10.1158/2326-6066.CIR13-0059- $\mathrm{T}$

128. Cheng PH, Lian S, Zhao R, Rao XM, McMasters KM, Zhou HS. Combination of autophagy inducer rapamycin and oncolytic adenovirus improves antitumor effect in cancer cells. Virol J (2013) 10:293. doi:10.1186/1743-422X-10-293

129. Heo J, Reid T, Ruo L, Breitbach CJ, Rose S, Bloomston M, et al. Randomized dose-finding clinical trial of oncolytic immunotherapeutic vaccinia JX-594 in liver cancer. Nat Med (2013) 19:329-36. doi:10.1038/nm.3089

130. Kim HS, Kim-Schulze S, Kim DW, Kaufman HL. Host lymphodepletion enhances the therapeutic activity of an oncolytic vaccinia virus expressing 41BB ligand. Cancer Res (2009) 69:8516-25. doi:10.1158/0008-5472.CAN-092522

131. Li J, O’Malley M, Urban J, Sampath P, Guo ZS, Kalinski P, et al. Chemokine expression from oncolytic vaccinia virus enhances vaccine therapies of cancer. Mol Ther (2011) 19:650-7. doi:10.1038/mt.2010.312

132. Yu F, Wang X, Guo ZS, Bartlett DL, Gottschalk SM, Song XT. T-cell engagerarmed oncolytic vaccinia virus significantly enhances antitumor therapy. $\mathrm{Mol}$ Ther (2014) 22:102-11. doi:10.1038/mt.2013.240
133. Hu W, Davis JJ, Zhu H, Dong F, Guo W, Ang J, et al. Redirecting adaptive immunity against foreign antigens to tumors for cancer therapy. Cancer Biol Ther (2007) 6:1773-9. doi:10.4161/cbt.6.11.4855

134. Kanerva A, Nokisalmi P, Diaconu I, Koski A, Cerullo V, Liikanen I, et al. Antiviral and antitumor T-cell immunity in patients treated with GM-CSF-coding oncolytic adenovirus. Clin Cancer Res (2013) 19:2734-44. doi:10.1158/10780432.CCR-12-2546

135. Workenhe ST, Mossman KL. Oncolytic virotherapy and immunogenic cancer cell death: sharpening the sword for improved cancer treatment strategies. Mol Ther (2014) 22:251-6. doi:10.1038/mt.2013.220

136. Janelle V, Langlois MP, Lapierre P, Charpentier T, Poliquin L, Lamarre A. The strength of the $\mathrm{T}$ cell response against a surrogate tumor antigen induced by oncolytic VSV therapy does not correlate with tumor control. Mol Ther (2014). doi:10.1038/mt.2014.34

Conflict of Interest Statement: David L. Bartlett is a scientific advisor for and has financial interest with Jennerex Biotherapeutics, a biopharmaceutical company developing oncolytic virotherapy. The other authors declare no conflict of interest.

Received: 07 February 2014; accepted: 24 March 2014; published online: 10 April 2014. Citation: Guo ZS, Liu Z and Bartlett DL (2014) Oncolytic immunotherapy: dying the right way is a key to eliciting potent antitumor immunity. Front. Oncol. 4:74. doi: 10.3389/fonc.2014.00074

This article was submitted to Tumor Immunity, a section of the journal Frontiers in Oncology.

Copyright (C) 2014 Guo, Liu and Bartlett. This is an open-access article distributed under the terms of the Creative Commons Attribution License (CC BY). The use, distribution or reproduction in other forums is permitted, provided the original author(s) or licensor are credited and that the original publication in this journal is cited, in accordance with accepted academic practice. No use, distribution or reproduction is permitted which does not comply with these terms. 